\title{
Split or straight? Evidence of the effects of work schedules on workers' well-being, time use, and productivity
}

\author{
Jorge González Chapela ${ }^{1}$
}

Received: 1 July 2014 / Accepted: 13 April 2015 / Published online: 16 May 2015

(C) The Author(s) 2015. This article is published with open access at SpringerLink.com

\begin{abstract}
About half of all employees in Spain are on a daytime split work schedule, i.e. they typically work for $5 \mathrm{~h}$ in the morning, take a 2 -hour break at lunch time, and work for another $3 \mathrm{~h}$ in the afternoon/evening. This paper studies the effects of split work schedule on workers' psychological well-being, daily time use, and productivity. Using cross-sectional data from the 2002 to 2003 Spanish Time Use Survey, I find that female split-shifters experience an increased feeling of being at least sometimes overwhelmed by tasks and not having enough time to complete them. On working days, a split work schedule is positively related to time spent on the job, sleeping, and eating and drinking, and negatively associated with time spent on housework, parental child care, and leisure activities. Most of the time-use effects are similar across the sexes, and only a few of the time reductions are partly made up on days off. I also find that the split work schedule is associated with lower hourly wages.
\end{abstract}

Keywords Split shifts · Role overload · Time use · Labor productivity · Spanish time use survey

JEL classification $\quad \mathrm{I} 31 \cdot \mathrm{J} 22 \cdot \mathrm{J} 24$

Electronic supplementary material The online version of this article (doi:10.1007/s13209-015-0125-2) contains supplementary material, which is available to authorized users.

$凶$ Jorge González Chapela

jorgegc@unizar.es

1 Academia General Militar, Centro Universitario de la Defensa de Zaragoza, Ctra. de Huesca s/n, 50090 Zaragoza, Spain 


\section{Introduction}

A prominent feature of the Spanish labor market is that many individuals work split shifts, consisting typically of $5 \mathrm{~h}$ work in the morning, a 2-h break at lunch time, and another $3 \mathrm{~h}$ work in the afternoon/evening. According to the Spanish Survey of Working Conditions, $52.2 \%$ of workers were on a daytime split work schedule in 2003, and $40.2 \%$ in 2011 (INSHT 2003, 2011). As a result, compared to other OECD countries, the distribution of working hours in Spain is quite wide and features a sharper dip in the middle of the day (see, e.g., Amuedo-Dorantes and de la Rica 2009).

The way the working day is organized can have far-reaching implications. For example, while there is compelling evidence that parental time is important for a child's cognitive development (e.g., see Del Boca et al. 2014), results in Rapoport and Le Bourdais (2008) indicate that working between 5 pm and 7 pm substantially reduces the time that parents spend with their children. More generally, working split shifts complicates the scheduling of family activities, which might have a bearing on the fact that the Spanish employment gender gap is one of the highest among OECD economies (Guner et al. 2014). Furthermore, ARHOE (2013) suggests that split shift workers may sleep substantially less than comparable straight-shifters, and insufficient sleep can impair the worker's productivity and psychological well-being (Akerstedt et al. 2009). Productivity, in turn, is one of the key determinants of wages.

The purpose of this paper is to examine empirically the effects that working split shifts have on Spanish workers' well-being, time use, and productivity (hourly wages). The study adds to the literature in several regards. For the US and Canada, Presser (e.g., 1988, 1994), Kostiuk (1990), and Williams (2008), among others, examine the prevalence and consequences of shift work, which they define as anything other than a regular daytime schedule. But since very few US and Canadian workers work split shifts, they do not specifically study split schedules. ${ }^{1}$ In contrast, this paper focuses on the split schedule, which is the normal daytime work schedule in Spain. AmuedoDorantes and de la Rica (2009) look at the effect of working split shifts on wages, and show that full-time workers are not compensated with higher wages for having such a schedule. But wage gaps may also result from productive characteristics, which offer an avenue for exploring the existence of differences in productivity across work schedules. ARHOE (2013) does contain a theoretical analysis of the consequences of the split work schedule for workers' time use and productivity, while the current paper studies these issues empirically.

One important limitation of this study is that the work schedule may not be entirely the result of a "random assignment". For example, individuals with a strong preference for having free time in the early evening could select themselves into sectors of employment, occupations, or even companies with widespread straight-shift jobs. This would be also the case of more able individuals if working straight shifts were considered to be more convenient (Amuedo-Dorantes and de la Rica 2009). Not taking into account the circumstances underlying the "assignment" of shift type could lead

\footnotetext{
1 According to the Bureau of Labor Statistics (2005), only $0.5 \%$ of US workers in 2004 worked split shifts. For Canada, the figure was $3.9 \%$ in 2005 (Williams 2008).
} 
to biased effects of the work schedule. Fortunately, the data set used in this paper, the 2002-2003 Spanish time use survey, does contain information on the worker's sector of employment, industry, and occupation, so that these characteristics can be held fixed in the analyses. However, the degree to which the worker's company allows them to choose their schedule is unknown. ${ }^{2}$ Although Amuedo-Dorantes and de la Rica (2009) instrument an employee's schedule by his/her partner's work schedule, the presence of assortative mating on unobserved preferences for leisure or on unobserved ability (e.g., Hamermesh 2002; Goux et al. 2014; Greenwood et al. 2014) would invalidate the proposed instrument. The same would occur with the size of the worker's firm if workers selected themselves into firms based upon the prevalence of shift types. These concerns limit the usefulness of an instrumental variable approach, which is not used in the current analysis.

The results suggest the existence of an increased feeling of being at least sometimes overwhelmed by tasks and not having enough time to complete them among female split-shifters. Holding other factors fixed, working split shifts increases average incidence of being overwhelmed for female full-time employees by $12 \%$. On working days, and for both men and women, a split work schedule is positively related to time spent working, eating and drinking, and sleeping, and negatively associated with time spent on housework, parental child care, and leisure activities. Again controlling for other factors, workers on split shift work about 37 min more per day (about $3 \mathrm{~h}$ per week) than workers in straight shift. The productivity of workers on a split schedule appears to be lower than that of comparable straight-shifters: split shift is associated with a 5.3 and $7.4 \%$ hourly wage penalty for females and males, respectively. The remainder of the paper is organized as follows. Section 2 describes the data and methods used. Section 3 presents the results. Section 4 provides some concluding observations. The Appendix at the end of the paper contains additional descriptive statistics, whereas the complete estimation output is presented in the Online Appendix.

\section{Data and methods}

\subsection{Data selection and construction of key measures}

The data for this study come from the 2002 to 2003 Spanish time use survey (STUS), a full-scale survey conducted by the Spanish statistical office (INE). The STUS gathered time-use information by the time diary method. Specifically, all household members aged 10 years and older were asked to list their main activity in every 10-min interval of the previous 24-h day (beginning at 6 am). ${ }^{3}$ These activities were then classified into

\footnotetext{
2 For example, the prevalence of split-shift jobs is larger in smaller companies (INSHT 2011).

3 To avoid seasonal distortions, the STUS size was distributed evenly between October 2002 and September 2003. Fernandez and Sevilla-Sanz (2006) compare some demographic and labor variables in the STUS with those in the economically active population survey (EAPS), finding few differences. Table 6 in the Appendix shows further comparisons from which the same conclusion can be drawn. Regarding the reliability of the diary instrument, the mean number of activity episodes (21.5), the very low prevalence of diaries with fewer than seven episodes $(0.1 \%)$, and the low presence of diaries missing two or more basic activities $(0.5 \%)$ all indicate the data is of good quality (Juster 1985; Robinson 1985; Fisher et al. 2012).
} 
standardized codes (listed in Annex VI of Eurostat 2004). The STUS also collected labor market and socio-demographic variables by means of additional questionnaires. ${ }^{4}$

The sample for the current analysis is made up of full-time employees aged 18-64 with just one job who did not work between $10 \mathrm{pm}$ and 6 am in any of the seven consecutive days surveyed by the STUS weekly schedule of working time (WSWT). ${ }^{5}$ I discarded the self-employed because they are more likely to select their preferred work schedule, which raises endogeneity issues. To be considered a full-time worker, an individual had to work at least $30 \mathrm{~h}$ per week. Restricting the sample to daytime workers with just one job was aimed at reducing heterogeneity. I also discarded individuals reporting fewer than seven episodes in the diary day, who missed two or more of the four basic activities defined in Fisher et al. (2012), or who presented missing or inconsistent data. Moreover, an individual with an unusually large sleeping time was dropped because it was considered an influential observation (Belsley et al. 1980). This left us with 10,517 individuals (and as many time diaries), of whom 4041 were women. However, and in order to isolate more precisely the effects of the work schedule, for the primary time-use analyses the sample was further restricted to individuals whose diary day was a regular working day. Thus, diaries featuring public holidays, vacations, or days missed through illness or other reasons were excluded. However, diaries including weekends were included if the diarist reported they worked regularly on that day. This yielded a sample size of 6409 individuals, of whom 2451 were women. Since the date of the diary was randomly assigned, demographic differences between both samples tended to be small. The proportion of females in both samples resembles that in the population of full-time employees $(36.7 \%$, obtained from the EAPS).

The indicator for the type of work schedule is constructed from the question What kind of work schedule do you have: split or straight? $50.8 \%$ of the sample report working split shifts (the corresponding population percentage is 52.5). As can be seen in Fig. 1, the straight work schedule takes place primarily in the morning. Table 1 presents the characteristics of split- and straight-shift workers. The split schedule is more frequent in the private sector, among men, managers, sales and construction workers, and in Catalonia, for example. The distribution of workers across industries and occupations differs by work schedules, but is similar across household income groups, which suggests the split shifts are, at least in part, demand-driven.

Role overload (RO) is the feeling of having too much to do and not enough time to do it (Williams 2008). I use two questions from the individual questionnaire to construct two measures of RO: How often do you feel overwhelmed by tasks: Very often, Sometimes, or Almost never? and Do you have too little time to do what you have to do? I explore two different measures because the empirical definition of RO, which is somewhat subjective, influences the results. Respondents answering Very often and Yes to these questions are considered to suffer from RO according to the

\footnotetext{
4 These additional questionnaires include the information needed to construct an indicator of role overload plus the employment sector (private or public), which are lacking in the 2009-2010 STUS. This is the main reason why the current analysis focuses on 2002-2003 survey.

5 The WSWT is filled in by all respondents holding a job and provides information on total working time. Its seventh day should coincide with the diary day.
} 


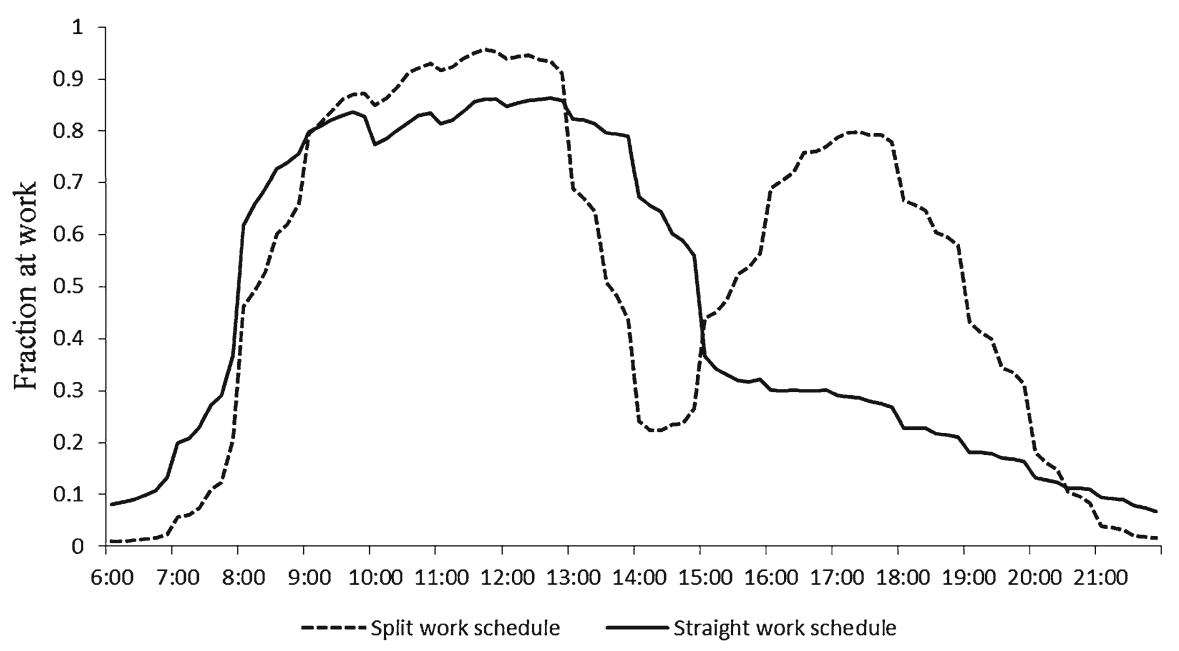

Fig. 1 Fraction at work on working days. Male and female full-time employees

first measure (ROM1). In the second measure (ROM2), the RO condition is assigned to those answering Very often/Sometimes and Yes. Irrespective of the measure, women are significantly more likely than men to be affected by RO (see Table 7 in the Appendix).

The five activities analyzed here (sleeping, eating and drinking, housework, child care, and leisure) appear often in discussions about work schedules in Spain (ARHOE 2013). Their definitions, given in Table 1, are standard. (This table also presents a definition and descriptive statistics for the estimate of market work derived from the time diary.) The proportion of working days with 0 min of sleep or eating and drinking is negligible, very small in the case of leisure, and much larger in the cases of housework (9.5\% of women and $41.0 \%$ of men) and child care $(36.7 \%$ of mothers and $57.1 \%$ of fathers). The information on weekly working hours was obtained from the WSWT unless the worker considered the surveyed week to be unusual, in which case their hours derived from a direct question (How many hours do you work per week?), asked of those whose employment contract specified the number of working hours. I call this measure HM1. For $76.5 \%$ of the sample HM1 was obtained from the WSWT, which includes overtime. An alternative measure, HM2, was taken from the direct question on working hours unless hours were not specified in the job contract, in which case the estimate from the WSWT was used. For $91.8 \%$ of the sample HM2 derives from the direct question, and since this was asked immediately after answering Yes to Do you have the number of weekly hours of work set?, HM2 seems to exclude overtime. Indeed, in the subsample of workers with working hours set and with the WSWT pertaining to a regular working week, HM1 > HM2 in $52.3 \%$ of cases. (The true percentage could be higher, as direct questions tend to be biased in the direction of over-reporting: Bound et al. 2001).

To assess the effect of the work schedule on worker productivity, I estimate Mincerian-like hourly wage regressions. Although wages may deviate from the 
Table 1 Worker characteristics by type of work schedule

\begin{tabular}{|c|c|c|c|c|c|c|c|c|c|}
\hline \multirow[t]{2}{*}{ Variable (min) } & \multicolumn{4}{|c|}{ Split shifters $(N=3315)$} & \multicolumn{4}{|c|}{ Straight shifters $(N=3094)$} & \multirow{2}{*}{$\begin{array}{l}\text { Difference in } \\
\text { means }\end{array}$} \\
\hline & Mean & SD & Min & Max & Mean & SD & Min & $\operatorname{Max}$ & \\
\hline Sleeping & 457 & 72 & 50 & 840 & 451 & 79 & 50 & 870 & $7 * * *$ \\
\hline Eating and drinking ${ }^{\mathrm{a}}$ & 94 & 38 & 10 & 330 & 87 & 35 & 0 & 270 & $7 * * *$ \\
\hline $\begin{array}{l}\text { Housework } \\
\qquad(\text { excl. child care })^{b}\end{array}$ & 57 & 74 & 0 & 490 & 97 & 96 & 0 & 700 & $-40 * * *$ \\
\hline Child care ${ }^{\mathrm{c}}$ & 11 & 34 & 0 & 450 & 20 & 49 & 0 & 470 & $-8 * * *$ \\
\hline Leisure $^{\mathrm{d}}$ & 160 & 95 & 0 & 690 & 181 & 109 & 0 & 720 & $-21 * * *$ \\
\hline Market work $\mathrm{e}^{\mathrm{e}}$ & 497 & 92 & 60 & 710 & 441 & 83 & 30 & 710 & $56 * * *$ \\
\hline $\begin{array}{r}\text { Commuting } \\
\text { (one-way) }\end{array}$ & 25 & 15 & 0 & 90 & 27 & 16 & 0 & 90 & $-2 * * *$ \\
\hline Commuting episodes & 3.0 & 1.1 & 0 & 4 & 2.1 & 0.7 & 0 & 4 & $1.0^{* * * *}$ \\
\hline Variable & \multicolumn{4}{|c|}{ Split shifters $(N=5340)$} & \multicolumn{4}{|c|}{ Straight shifters $(N=5177)$} & \\
\hline $\begin{array}{l}\text { Weekly hrs. of work } \\
\text { Measure } 1 \text { (HM1) }\end{array}$ & 43.4 & 6.8 & 30 & 71 & 39.5 & 6.3 & 30 & 70 & $3.9^{* * *}$ \\
\hline $\begin{array}{l}\text { Weekly hrs. of work } \\
\text { Measure } 2 \text { (HM2) }\end{array}$ & 40.5 & 3.8 & 30 & 60 & 38.9 & 3.8 & 30 & 60 & $1.6^{* * * *}$ \\
\hline $\begin{array}{l}\text { Average hourly wage } \\
\text { Measure } 1\end{array}$ & 6.0 & 3.3 & 1.5 & 27.4 & 6.8 & 3.6 & 1.6 & 32.6 & $-0.8 * * *$ \\
\hline $\begin{array}{l}\text { Average hourly wage } \\
\text { Measure } 2\end{array}$ & 6.3 & 3.4 & 1.7 & 27.9 & 6.8 & 3.5 & 1.7 & 27.9 & $-0.5 * * *$ \\
\hline $\begin{array}{l}\text { Overtime (hours per } \\
\text { week) }^{\mathrm{f}}\end{array}$ & 7.2 & 5.7 & 0.1 & 33.5 & 6.4 & 5.6 & 0.2 & 30.3 & $0.8 * * *$ \\
\hline \multicolumn{10}{|l|}{ Variable $(\%)$} \\
\hline $\begin{array}{l}\text { Role overload } \\
\text { Measure } 1\end{array}$ & 8.1 & & & & 9.5 & & & & $-1.4 * *$ \\
\hline $\begin{array}{l}\text { Role overload } \\
\text { Measure } 2\end{array}$ & 28.8 & & & & 29.2 & & & & -0.5 \\
\hline Private sector & 89.5 & & & & 61.8 & & & & $27.7 * * *$ \\
\hline $\begin{array}{l}\text { Flexible work } \\
\text { schedule }\end{array}$ & 22.3 & & & & 18.2 & & & & $4.2 * * *$ \\
\hline Works overtime $^{\mathrm{f}}$ & 65.4 & & & & 38.0 & & & & $27.3 * * *$ \\
\hline Female & 33.1 & & & & 43.9 & & & & $-10.8 * * *$ \\
\hline Age $\leq 30$ & 31.3 & & & & 21.6 & & & & $9.7 * * *$ \\
\hline $31-35$ & 13.9 & & & & 13.0 & & & & 0.9 \\
\hline $36-40$ & 14.6 & & & & 15.6 & & & & -1.1 \\
\hline $41-45$ & 13.0 & & & & 16.7 & & & & $-3.7 * * *$ \\
\hline $46-50$ & 10.7 & & & & 14.2 & & & & $-3.5 * * *$ \\
\hline$\geq 51$ & 16.5 & & & & 18.9 & & & & $-2.4 * * *$ \\
\hline $\begin{array}{l}\text { Spouse/partner } \\
\text { present }\end{array}$ & 62.2 & & & & 68.7 & & & & $-6.5 * * *$ \\
\hline
\end{tabular}


Table 1 continued

\begin{tabular}{|c|c|c|c|}
\hline \multicolumn{4}{|l|}{ Variable (\%) } \\
\hline Presence of children [0-5] & 16.3 & 16.9 & -0.6 \\
\hline Presence of children [6-17] & 26.6 & 32.6 & $-6.0 * * *$ \\
\hline Household with 1 adult & 4.9 & 5.6 & -0.7 \\
\hline 2 adults & 43.1 & 46.1 & $-3.0 * * *$ \\
\hline 3 adults & 23.4 & 22.8 & 0.5 \\
\hline $4+$ adults & 28.7 & 25.5 & $3.2 * * *$ \\
\hline Less than high school graduate & 47.9 & 42.1 & $5.8 * * *$ \\
\hline High school graduate ${ }^{g}$ & 31.1 & 33.3 & $-2.3 * *$ \\
\hline University degree & 21.0 & 24.6 & $-3.6^{* * *}$ \\
\hline Disabled & 9.4 & 11.8 & $-2.5 * * *$ \\
\hline Manager & 2.9 & 1.6 & $1.3 * * *$ \\
\hline Technician/professional & 11.9 & 15.1 & $-3.2 * * *$ \\
\hline Supporting technician/prof. & 17.1 & 13.8 & $3.3 * * *$ \\
\hline Clerical worker & 8.0 & 12.0 & $-4.1^{* * *}$ \\
\hline Service worker ${ }^{\mathrm{h}}$ & 4.1 & 11.0 & $-6.8 * * *$ \\
\hline Sales worker & 8.3 & 3.9 & $4.4 * * *$ \\
\hline Craftsman or related worker & 27.5 & 16.7 & $10.9 * * *$ \\
\hline Operator & 8.4 & 10.6 & $-2.1 * * *$ \\
\hline Unskilled worker & 11.8 & 15.4 & $-3.7 * * *$ \\
\hline Agriculture ${ }^{\mathrm{i}}$ & 3.5 & 3.5 & 0.0 \\
\hline Manufacturing & 22.6 & 21.4 & 1.2 \\
\hline Construction & 20.1 & 6.3 & $13.9 * * *$ \\
\hline Trade & 20.1 & 8.6 & $11.5^{* * *}$ \\
\hline Hotel industry & 2.0 & 4.8 & $-2.8 * * *$ \\
\hline Transport & 4.5 & 5.3 & -0.8 \\
\hline Financial intermediation & 2.4 & 4.7 & $-2.3 * * *$ \\
\hline Real state & 8.8 & 5.2 & $3.6 * * *$ \\
\hline Public administration & 3.3 & 17.6 & $-14.3 * * *$ \\
\hline Educational services & 5.9 & 6.9 & $-1.1^{* *}$ \\
\hline Health services & 2.4 & 10.9 & $-8.5 * * *$ \\
\hline Other services & 4.4 & 4.8 & -0.4 \\
\hline Adult care & 2.3 & 2.9 & -0.6 \\
\hline Net monthly household income $<500$ & 0.8 & 0.7 & 0.1 \\
\hline 500-999.99 & 10.2 & 9.0 & $1.1^{* *}$ \\
\hline 1000-1499.99 & 23.3 & 22.0 & 1.3 \\
\hline 1500-1999.99 & 22.0 & 22.1 & -0.1 \\
\hline 2000-2499.99 & 17.3 & 18.7 & -1.4 \\
\hline $2500-2999.99$ & 10.9 & 11.0 & -0.1 \\
\hline $3000-4999.99$ & 13.2 & 14.2 & -1.0 \\
\hline$\geq 5000$ & 2.3 & 2.3 & 0.1 \\
\hline
\end{tabular}


Table 1 continued

\begin{tabular}{|c|c|c|c|}
\hline \multicolumn{4}{|l|}{ Variable $(\%)$} \\
\hline Andalucía & 14.8 & 20.8 & $-6.0 * * *$ \\
\hline Aragón & 2.3 & 2.9 & -0.5 \\
\hline Asturias & 2.6 & 3.1 & -0.5 \\
\hline Baleares & 2.1 & 2.8 & $-0.7 * *$ \\
\hline Canarias & 3.2 & 5.6 & $-2.5 * * *$ \\
\hline Cantabria & 3.0 & 3.2 & -0.2 \\
\hline Castilla y León & 4.8 & 4.4 & 0.4 \\
\hline Castilla-La Mancha & 3.6 & 3.5 & 0.1 \\
\hline Cataluña & 21.9 & 14.0 & $7.8^{* * *}$ \\
\hline Comunidad Valenciana & 7.4 & 5.6 & $1.8 * * *$ \\
\hline Extremadura & 1.6 & 2.2 & $-0.6^{* *}$ \\
\hline Galicia & 8.9 & 6.6 & $2.3 * * *$ \\
\hline Comunidad de Madrid & 9.3 & 10.2 & -0.9 \\
\hline Región de Murcia & 3.6 & 2.4 & $1.2 * * *$ \\
\hline Navarra & 4.0 & 5.6 & $-1.6^{* * *}$ \\
\hline País Vasco & 2.8 & 2.5 & 0.3 \\
\hline La Rioja & 2.7 & 2.2 & 0.5 \\
\hline Ceuta y Melilla & 1.3 & 2.2 & $-0.9 * * *$ \\
\hline
\end{tabular}

The middle and lower panels refer to the complete sample of full-time employees, and the upper panel to the subsample whose diary day was a regular working day. Money variables are in euros of 2002/2003

Source: Spanish time use survey, 2002-2003, INE

** Significant at the $5 \%$ level, *** significant at the $1 \%$ level

${ }^{a}$ Includes lunch break at work

$\mathrm{b}$ Time spent on food management, household upkeep, making and care for textiles, gardening and pet care, construction and repairs, shopping for consumer goods and services, household management, and help to adult family members

${ }^{\mathrm{c}}$ Parents only

$\mathrm{d}$ Time spent on social life and entertainment, sports and outdoor activities, hobbies and games, and mass media

${ }^{\mathrm{e}}$ Excludes coffee and other breaks and on-the-job training

${ }^{\mathrm{f}}$ Employees with working hours set and whose weekly schedule of working time pertains to a regular working week. An employee works overtime when HM1 > HM2; the amount of overtime is calculated as HM1 - HM2

g Includes vocational training

$\mathrm{h}$ Includes the military

${ }^{\mathrm{i}}$ Includes extractive industries

worker's current productivity (e.g., see Manning 2010), the lack of a compensatory premium for working split shifts (Amuedo-Dorantes and de la Rica 2009) plus the rich set of controls (discussed in Sect. 2.2) included in the wage regressions, strongly suggest that the existence of wage differences across work schedules reflects, at least in part, differences in productivity. Following Bell and Hart (1999) and Anger (2008), I explore two different measures of the hourly wage to account for possible differences in unpaid work across work schedules. The first measure (WM1) is calculated 
as average net monthly earnings divided by HM1 times 4.3. ${ }^{6}$ The second measure (WM2) has as denominator HM2 times 4.3. According to Bell and Hart (1999), WM1 is a superior measure of productivity because actual wages are adjusted between highand low-productivity workers by requiring the latter to undertake unpaid overtime. However, if unpaid overtime is used in fact by workers to signal a higher value to the firm (Anger 2008), WM2 would be preferred.

As shown in Table 1, split-shifters spend less time on leisure, domestic, and child care activities, but spend more time sleeping, eating, and working in the market. The extent of overtime work is larger among split-shifters, but their hourly wage is lower, as is the incidence of ROM1 among this group. To ensure that these outcomes are not the result of composition effects, the estimating models will include control variables, described in Table 8 by gender.

\subsection{Estimation methods}

\subsubsection{Role overload}

A probit model is used to investigate whether worker $i$ experiences RO. Let $y_{i}$ be a random variable of value 1 if $i$ experiences RO and of value 0 otherwise. The response probability $P\left(y_{i}=1 \mid x_{i}\right)$ is specified as

$$
P\left(y_{i}=1 \mid x_{i}\right)=\Phi\left(x_{i}^{\prime} \beta\right),
$$

where $x_{i}$ is the vector of explanatory variables, $\beta$ is an unknown parameter vector, and $\Phi(\cdot)$ denotes the standard normal cdf. The probit estimate $\hat{\beta}$ is obtained by maximizing $\sum_{i=1}^{N} \ell_{i}(\beta)$, where

$$
\ell_{i}(\beta)=y_{i} \ln \left[\Phi\left(x_{i}^{\prime} \beta\right)\right]+\left(1-y_{i}\right) \ln \left[1-\Phi\left(x_{i}^{\prime} \beta\right)\right]
$$

and $\ln (\cdot)$ is the natural $\log$ function. From the general maximum likelihood results, $\hat{\beta}$ is consistent and asymptotically normal (e.g., see Wooldridge 2010). The marginal effect of the $j$ th regressor on $P\left(y_{i}=1 \mid x_{i}\right)$ is $\Phi\left(x_{i}^{\prime} \beta \mid x_{i j}=1\right)-\Phi\left(x_{i}^{\prime} \beta \mid x_{i j}=0\right)$ if $x_{j}$ is binary, and $\phi\left(x_{i}^{\prime} \beta\right) \beta_{j}$ if $x_{j}$ is continuous, $\phi(\cdot)$ being the standard normal pdf. In both cases, the marginal effect is estimated by plugging in $\hat{\beta}$ and then averaging across observations. Standard errors of marginal effects clustered at the household level are calculated with the delta method.

The controls included in $x_{i}$ (dummies for age, presence of a spouse/partner, presence of children aged $0-5$ and 6-17, presence of other adults beyond the spouse/partner, disability, education, industry, occupation, flexible work schedule, weekly hours worked, help to adult family members, and household income) are those in Williams (2008) with the exception of job satisfaction, level of stress, and seeing oneself as a workaholic,

\footnotetext{
${ }^{6}$ Monthly earnings are given in intervals. I take the midpoint of each interval except when individuals claim less than 500 euros (in which case I assign them the minimum monthly wage) and when they claim 3000 euros or more (in which case I assign them 4205 euros, which is the mean of a Pareto curve fitted to the upper end of the earnings distribution: Ligon 1994). On average there are 4.3 weeks per month.
} 
which are not available in the STUS. I have also included a sector-of-employment dummy to mitigate the possible endogeneity of the work schedule, plus dummies for region of residence. If an unobserved preference for having free time in the early evening (respectively, unobserved ability) made the worker more (less) sensitive to feeling role overloaded, the estimated effect of the split schedule would be biased in the negative (positive) direction if that preference (unobserved ability) were lower among split shift workers. Of course, the argument works mutatis mutandis for the time allocation and productivity regressions.

\subsubsection{Time allocation}

Choosing a specification and estimation method for $E\left(t_{i m} \mid x_{i}\right)$, where $t_{i m}$ is time spent on activity $m$, is complicated by the presence of diaries with zeros. Presumably, zeros pertain to two kinds of individuals: those who never do $m$ (non-doers), and doers who, on the diary day, spent no time on $m$ (called reference-period-mismatch zeros by Stewart 2013). The latter type introduces measurement error in $t_{i m}$, which renders the Tobit estimator inconsistent (Stapleton and Young 1984). While the ordinary least squares (OLS) estimator is also inconsistent in the Tobit context, Stoker (1986) finds that if $x_{i}$ is multivariate normally distributed, OLS consistently estimates Tobit's marginal effects. A similar conclusion was reached by Greene (1981), whose Monte Carlo study further suggests that such a result is robust in the presence of uniformly distributed and binary explanatory variables, but is distorted by the presence of skewed variables in $x_{i}$. Stewart (2013) has recently simulated the behavior of the OLS estimator with time-diary data, and produced results consistent with Greene's (1981). ${ }^{7}$ The reason behind the apparent robustness of OLS may be that the presence of (random) measurement error in $t_{i m}$ is inconsequential when the estimating model is linear. Overall, therefore, the combination of a linear specification

$$
E\left(t_{i m} \mid x_{i}\right)=x_{i}^{\prime} \gamma_{m}
$$

where $\gamma_{m}$ is a vector of unknown parameters, with an OLS estimator is a reasonable compromise for estimating $E\left(t_{i m} \mid x_{i}\right)$, particularly if, as in this study, the explanatory variables adopt the format recommended by Greene (1981) and Stoker (1986). Another reason for choosing OLS is that most error terms in the time-use equations appeared as heteroskedastic, whereby system homoskedasticity does not hold (Wooldridge 2010, Chapter 7). In the absence of system homoskedasticity, system OLS is preferred to the less robust system feasible generalized least squares estimator, and without crossequation restrictions on the gamma parameters, OLS performed activity by activity is equivalent to system OLS. The explanatory variables for the use of time change only slightly with respect to those included in the model for RO: working hours are measured from the time diary estimate, and controls are added for season of the year and day of the week.

\footnotetext{
7 The regressors in Stewart's data-generating process are a dummy and two uniformly distributed variables.
} 


\subsubsection{Productivity}

Wage regression takes the standard form

$$
E\left(\ln \left(\mathrm{WM} k_{i}\right) \mid x_{i}\right)=x_{i}^{\prime} \pi_{k}, \quad(k=1,2),
$$

where $\pi_{k}$ is a vector of unknown coefficients. The quantity $100 \pi_{k j}$ is the semi-elasticity of WM $k$ with respect to $x_{i j}$. Since (4) applies to the population of workers ( $x_{i}$ contains the type of work schedule, and this is not defined for non-workers), no sample selection correction is attempted and (4) is estimated by OLS. The controls included in $x_{i}$ are those in the model for RO with the exception of working hours and household income, which have been removed because of endogeneity concerns.

\section{Results}

\subsection{Role overload}

Table 2 presents selected probit marginal effects for the RO condition (the complete estimation output is in Tables B.1 and B.2 in the Online Appendix). The upper panel presents results for the full sample and the lower shows results for home owners whose diary day was a working day. In both cases, the first two columns contain results for women and the last two results for men. Effects on ROM1 are in odd columns, while those on ROM2 are in even ones.

In the full sample, the type of schedule is unrelated to the incidence of $\mathrm{RO}$ according to ROM1: For both women and men, the estimated marginal effect on the split-shifts dummy is small and statistically no different from zero at the $5 \%$ level. Women with a physical or mental disability are 0.096 more likely to experience $\mathrm{RO}$, whereas the corresponding effect for men is 0.066 . Since the average incidence of ROM1 is, respectively, 0.137 and 0.057 , disability status increases that probability by around 70 and $116 \%$. For women, being a manager increases the likelihood of suffering from RO by around $102 \%$ with respect to a comparable female clerical worker. Working more than $40 \mathrm{~h}$ per week increases the incidence of $\mathrm{RO}$ for women, but not for men.

The broader definition of RO (ROM2) has a pronounced effect on the impact of working split shifts for women, the estimated marginal effect of which becomes much larger and statistically different from zero at the $1 \%$. Holding other factors fixed, female full-time employees are, on average, 0.048 more likely to experience RO when working split shifts, which represents a $12 \%$ increase in the average incidence of ROM2 (0.394). In contrast, the type of schedule is again unrelated to the incidence of RO for men. These effects are lower in magnitude than those reported in Williams (2008), where Canadian workers (both men and women) on anything other than a regular daytime schedule were about $15 \%$ less likely than day workers to have no role overload.

The journey to work exposes people to environmental and psychological stressors (e.g., see Koslowsky et al. 1995), meaning that the characteristics of the commute could have a bearing on the incidence of RO. I re-estimated the model for RO on home 
Table 2 Probit equations for suffering from role overload (selected marginal effects)

\begin{tabular}{|c|c|c|c|c|c|c|c|c|}
\hline \multirow{3}{*}{$\begin{array}{l}\text { Full sample } \\
\text { Independent variables }\end{array}$} & \multicolumn{4}{|l|}{ Women } & \multicolumn{4}{|l|}{ Men } \\
\hline & \multicolumn{2}{|l|}{ (1) ROM1 } & \multicolumn{2}{|l|}{ (2) ROM2 } & \multicolumn{2}{|l|}{ (3) ROM1 } & \multicolumn{2}{|l|}{ (4) ROM2 } \\
\hline & $\mathrm{ME}$ & SE & $\mathrm{ME}$ & SE & ME & SE & $\mathrm{ME}$ & SE \\
\hline Split shifts & -0.002 & 0.012 & $0.048 * * *$ & 0.017 & -0.006 & 0.006 & -0.013 & 0.012 \\
\hline Disabled & $0.096 * * *$ & 0.021 & $0.135 * * *$ & 0.025 & $0.066 * * *$ & 0.012 & $0.099 * * *$ & 0.018 \\
\hline Manager & $0.140 * *$ & 0.067 & 0.135 & 0.071 & 0.030 & 0.025 & 0.059 & 0.039 \\
\hline Weekly hours $<40$ & -0.005 & 0.015 & 0.038 & 0.021 & -0.013 & 0.008 & $-0.036^{* *}$ & 0.015 \\
\hline Weekly hours $>40$ & $0.031 * *$ & 0.016 & $0.084 * * *$ & 0.021 & -0.000 & 0.007 & 0.019 & 0.013 \\
\hline Log-likelihood & -1499 & & -2482 & & -1317 & & -3184 & \\
\hline$R$-squared & 0.070 & & 0.084 & & 0.075 & & 0.078 & \\
\hline Observations & 4041 & & 4041 & & 6476 & & 6476 & \\
\hline \multirow{2}{*}{$\begin{array}{l}\text { Home owners observed on } \\
\text { working days }\end{array}$} & \multicolumn{4}{|l|}{ Women } & \multicolumn{4}{|l|}{ Men } \\
\hline & \multicolumn{2}{|l|}{ (5) ROM1 } & \multicolumn{2}{|l|}{ (6) ROM2 } & \multicolumn{2}{|l|}{ (7) ROM1 } & \multicolumn{2}{|l|}{ (8) ROM2 } \\
\hline Independent variables & $\mathrm{ME}$ & SE & ME & SE & ME & SE & $\mathrm{ME}$ & SE \\
\hline Split shifts & -0.014 & 0.019 & $0.073 * * *$ & 0.027 & -0.019 & 0.010 & -0.026 & 0.018 \\
\hline Commute duration $(10 \mathrm{~min})$ & $0.013 * * *$ & 0.005 & 0.014 & 0.008 & 0.004 & 0.002 & $0.009 * *$ & 0.005 \\
\hline Commuting episodes & -0.002 & 0.009 & -0.007 & 0.013 & 0.008 & 0.004 & 0.012 & 0.008 \\
\hline Log-likelihood & -726 & & -1246 & & -594 & & -1588 & \\
\hline$R$-squared & 0.106 & & 0.107 & & 0.109 & & 0.091 & \\
\hline Observations & 2076 & & 2076 & & 3229 & & 3229 & \\
\hline
\end{tabular}

The upper panel shows results for the complete sample of full-time employees, and the lower panel for the subsample of home owners whose diary day was a regular working day. In both panels, the set of controls includes an intercept plus dummies for age, presence of a spouse/partner, presence of children aged 0-5 and 6-17, presence of other adults beyond the spouse/partner, disability, education, sector of employment, industry, occupation, flexible work schedule, weekly hours worked, help to adult family members, household income, and region of residence. The complete set of marginal effects is shown in Tables B.1 and B.2 in the Online Appendix. Standard errors clustered at the household level are calculated with the delta method Source: Spanish time use survey, 2002-2003, INE

** Significant at the $5 \%$ level, *** significant at the $1 \%$ level

owners whose diaries pertain to working days, adding the duration of the commute and the number of commuting episodes to the set of explanatory variables. ${ }^{8}$ Home owners may feel less inclined than tenants to change address and thus to adjusting their commute, which reduces endogeneity concerns. The commute duration is associated with a higher likelihood of RO. For women, a 10-min increase in the commute increases that likelihood by around $10 \%$ (ROM1) and $3 \%$ (ROM2). For men the corresponding increases are 7 and $4 \%$. In contrast, the number of commuting episodes is generally unrelated to suffering from RO. Working split shifts increases the incidence of ROM2

\footnotetext{
8 The average duration of the commute is $2 \mathrm{~min}$ lower for split-shifters, though their mean number of daily commuting episodes is larger (see Table 1).
} 
by $18 \%$ among female home owners, but offers some protection to male home owners in terms of ROM1 (this effect is significant at the $10 \%$ ).

\subsection{Time allocation}

Discussions about the consequences of the work schedule on the organization of people's time implicitly assume that working hours do not differ by type of schedule. Yet, according to the labor supply estimates in Table 1, split-shifters provide more hours. To ensure that this outcome is not due to composition effects, I have estimated reducedform regressions for time spent working for pay. The main results are presented in Table 3 (the complete set of estimates is in Tables B.3-B.5 in the Online Appendix). ${ }^{9}$ As shown in the upper panel, split-shifters spend, on average, some 37 min longer working per day than comparable straight-shifters, that is, $3.1 \mathrm{~h}$ more per week if they work 5 days a week. The gap derived from HM1 (presented in the middle panel) is somewhat smaller, whereas that obtained from HM2 (lower panel) is below 1 hour per week for both sexes. Since HM2 seems to exclude overtime, these results also suggest that split-shifters provide significantly more overtime work than straight-shifters. To take account of the different working hours, time on the job is included among the controls in the time-use regressions. However, commuting time is not included, because the time saved by being on a straight schedule (implicit in the figures given in Table 1) could be devoted to alternative activities.

The two panels in Table 4 present the effects of working split shifts on the allocation of time by gender (the effects exerted by the controls are in Tables B.6 and B.7). The regressions for time spent sleeping, eating and drinking, doing housework, and at leisure, are estimated for individuals whose diaries pertain to working days. However, the regressions for child-care time [estimations (4) and (9)] are run on parents only, thus relaxing the assumption that child care falls continuously to zero in response to variations in the explanatory variables. Since the sample of parents might not be a random sample, I estimated a probit model for the decision to have children over the entire sample of individuals, relating the probability of having children to the whole set of regressors included in the regressions for child care with the exception of the dummies for the presence of children aged $0-5$ and 6-17, as these predict the outcome perfectly. I then obtained the estimated inverse Mills ratio for each individual, which was included in the OLS regressions for child care run on parents only. ${ }^{10}$ Standard errors in Table 4 are clustered at the household level, but those in estimations (4) and (9) are additionally robust to generated regressors (as in Arellano and Meghir 1992, Appendix B.4).

\footnotetext{
9 With respect to the other time-use regressions, I have replaced household income (which is endogenous in a model for working time) with the worker's non-labor income.

10 The evidence in Gimenez-Nadal and Molina (2013) suggests that educational attainment could help identifying the sample selection model for fathers. Nevertheless, the education dummies appeared as both individually and jointly insignificant in the probit for being a father (see Table B.8 in the Online Appendix; the joint test's $p$-value was 0.85 ).
} 
Table 3 Labor supply

\begin{tabular}{|c|c|c|c|c|}
\hline \multirow{2}{*}{$\begin{array}{l}\text { Minutes spent on the job on working days } \\
\text { Independent variables }\end{array}$} & \multicolumn{2}{|l|}{$\begin{array}{l}\text { Women } \\
\text { (1) }\end{array}$} & \multicolumn{2}{|l|}{$\begin{array}{l}\text { Men } \\
(2)\end{array}$} \\
\hline & Coefficient & SE & Coefficient & SE \\
\hline Split shifts & $37 * * *$ & 4 & $38 * * *$ & 3 \\
\hline$R$-squared & 0.194 & & 0.231 & \\
\hline Observations & 2451 & & 3958 & \\
\hline \multirow[t]{2}{*}{ Weekly hours of work (Measure 1) } & \multirow{2}{*}{\multicolumn{2}{|c|}{$\begin{array}{l}\text { Women } \\
\text { (3) }\end{array}$}} & \multirow{2}{*}{\multicolumn{2}{|c|}{$\begin{array}{l}\text { Men } \\
\text { (4) }\end{array}$}} \\
\hline & & & & \\
\hline Independent variables & Coefficient & SE & Coefficient & SE \\
\hline Split shifts & $2.2 * * *$ & 0.2 & $2.6 * * *$ & 0.2 \\
\hline$R$-squared & 0.220 & & 0.185 & \\
\hline Observations & 4041 & & 6476 & \\
\hline \multirow[t]{2}{*}{ Weekly hours of work (Measure 2) } & \multirow{2}{*}{\multicolumn{2}{|c|}{$\begin{array}{l}\text { Women } \\
(5)\end{array}$}} & \multirow{2}{*}{\multicolumn{2}{|c|}{$\begin{array}{l}\text { Men } \\
(6)\end{array}$}} \\
\hline & & & & \\
\hline Independent variables & Coefficient & SE & Coefficient & $\mathrm{SE}$ \\
\hline Split shifts & $0.9 * * *$ & 0.1 & $0.8 * * *$ & 0.1 \\
\hline$R$-squared & 0.220 & & 0.152 & \\
\hline Observations & 3934 & & 6359 & \\
\hline
\end{tabular}

Selected OLS estimates. The middle and lower panels show results for the complete sample of full-time employees, and the upper panel for the subsample whose diary day was a regular working day. In all panels, the set of controls includes an intercept, the log of the worker's non-labor income, plus dummies for age, presence of a spouse/partner, presence of children aged 0-5 and 6-17, presence of other adults beyond the spouse/partner, disability, education, sector of employment, industry, occupation, flexible work schedule, help to adult family members, season of the year, and region of residence. Additionally, the set of controls in the estimations shown in the upper panel includes dummies for day of the week. The complete set of estimates is shown in Tables B.3-B.5 in the Online Appendix. Standard errors are clustered at the household level

Source: Spanish time use survey, 2002-2003, INE *** Significant at the $1 \%$ level

Working split shifts is associated with more time spent sleeping on working days: on average, $12 \mathrm{~min}$ more for women and $8 \mathrm{~min}$ more for men. Estimates are precise and attain statistical significance at the $1 \%$ level. To investigate the reason behind this difference, I re-estimated the regression for sleeping time on observations for each hour of the day (i.e. time spent sleeping between 6 and 7 am, 7 and 8 am, and so on). Figure 2 depicts the sign and size of the statistically significant effects associated with working split shifts, by time of day and sex. Workers on a straight schedule wake up earlier, but don't generally go to bed earlier. Although straight-shifters take a (longer) nap in the afternoon, its duration does not compensate for sleep lost in the morning. Hamermesh et al. (2008) have found that television schedules affect the timing of 
Table 4 Time use on working days (minutes)

\begin{tabular}{|c|c|c|c|c|c|c|c|c|c|c|}
\hline \multirow{2}{*}{$\begin{array}{l}\text { Women } \\
\text { Independent } \\
\text { variables }\end{array}$} & \multicolumn{2}{|l|}{ (1) } & \multicolumn{2}{|l|}{ (2) } & \multicolumn{2}{|l|}{ (3) } & \multicolumn{2}{|l|}{ (4) } & \multicolumn{2}{|l|}{ (5) } \\
\hline & Sleep & SE & $\begin{array}{l}\text { Eating and } \\
\text { drinking }\end{array}$ & SE & Housework & SE & Child care & SE & Leisure & $\mathrm{SE}$ \\
\hline Split shifts & $12 * * *$ & 4 & $7 * * *$ & 2 & $-12 * * *$ & 4 & -3 & 5 & -7 & 4 \\
\hline$R$-squared & 0.113 & & 0.068 & & 0.404 & & 0.399 & & 0.246 & \\
\hline Observations & 2451 & & 2451 & & 2451 & & 841 & & 2451 & \\
\hline Men & (6) & & (7) & & (8) & & (9) & & (10) & \\
\hline $\begin{array}{l}\text { Independent } \\
\text { variables }\end{array}$ & Sleep & SE & $\begin{array}{l}\text { Eating and } \\
\text { drinking }\end{array}$ & SE & Housework & SE & Child care & SE & Leisure & $\mathrm{SE}$ \\
\hline Split shifts & $8 * * *$ & 3 & $5 * * *$ & 1 & $-11 * * *$ & 2 & $-10^{* * *}$ & 3 & -7 & 4 \\
\hline$R$-squared & 0.081 & & 0.067 & & 0.220 & & 0.276 & & 0.247 & \\
\hline Observations & 3958 & & 3958 & & 3958 & & 1602 & & 3958 & \\
\hline
\end{tabular}

Selected OLS estimates. The table shows results for the subsample of full-time employees whose diary day was a regular working day, except the estimations for child-care time, which are run on parents only. In all estimations, the set of controls includes an intercept, the amount of minutes spent on the job, plus dummies for age, presence of a spouse/partner, presence of children aged 0-5 and 6-17, presence of other adults beyond the spouse/partner, disability, education, sector of employment, industry, occupation, flexible work schedule, help to adult family members, season of the year, day of the week, household income, and region of residence. Additionally, estimations (4) and (9) include an inverse Mills ratio term accounting for potential selectivity bias into the decision to have children. The complete set of estimates is shown in Tables B.6 and B.7 in the Online Appendix. Standard errors are clustered at the household level; in estimations (4) and (9), they are additionally robust to generated regressors

Source: Spanish time use survey, 2002-2003, INE

** Significant at the $5 \%$ level, *** significant at the $1 \%$ level

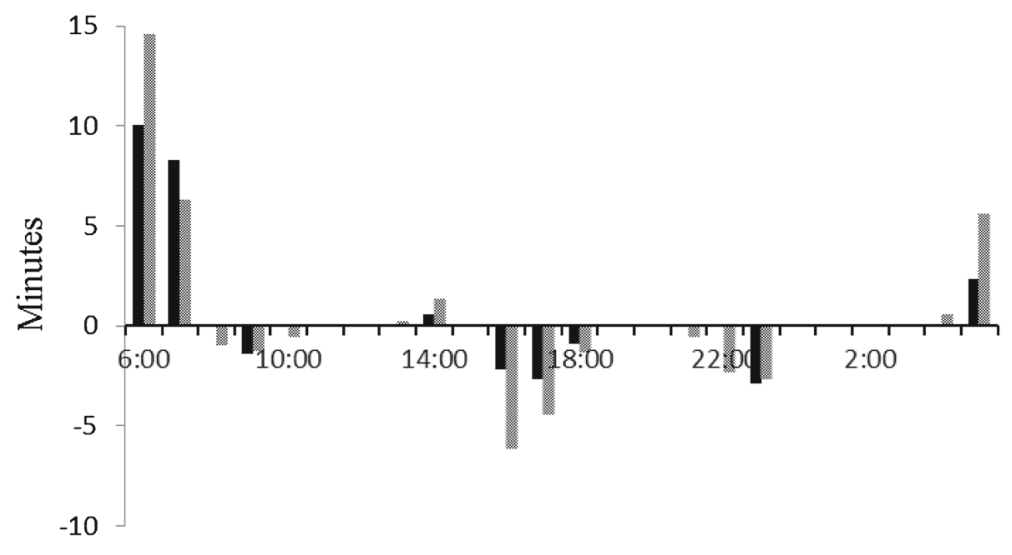

Women Men

Fig. 2 Effects of working split shifts on time spent sleeping on working days, by time of day and sex. The effects represented are those achieving statistical significance at the $5 \%$ level 


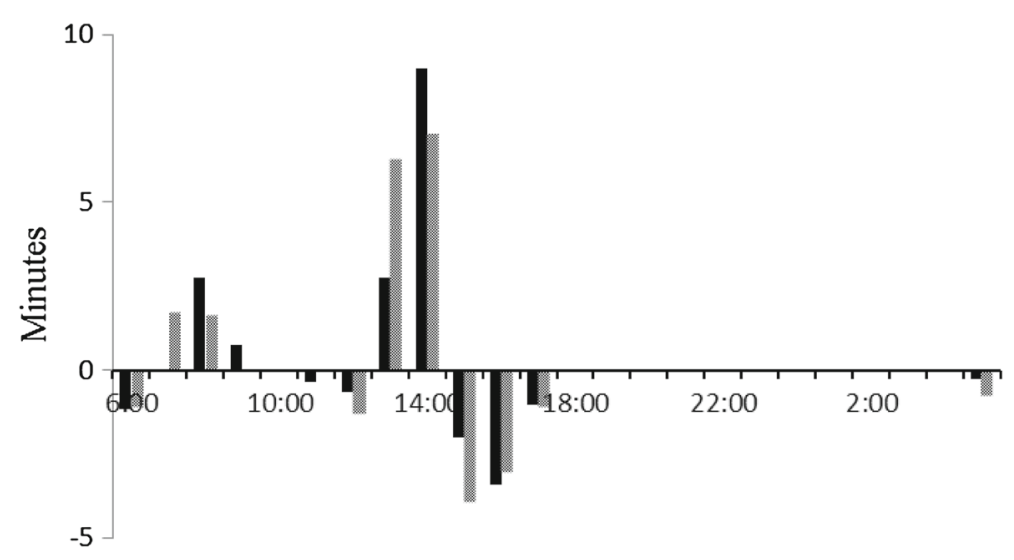

- Women Men

Fig. 3 Effects of working split shifts on time spent eating and drinking on working days, by time of day and sex.The effects represented are those achieving statistical significance at the $5 \%$ level

work and sleep. In Spain, television programming is traditionally linked to the split work schedule, but this practice seems to be causing straight-shifters to sleep less. ${ }^{11}$

Working split shifts is also associated with more time spent eating and drinking on working days: $7 \mathrm{~min}$ more for women and $5 \mathrm{~min}$ more for men. Estimates, again, are precise and attain statistical significance at the $1 \%$. Figure 3, which is constructed analogously to Fig. 2, shows that this difference derives essentially from the duration of lunch. Table B.9 presents the effects of working split shifts on those workers having lunch and on eating and drinking at home, on the job, or in a restaurant, all between 1 and $5 \mathrm{pm}$. On average, working split shifts increases the proportion of women who eat at home or in a restaurant and reduces the proportion of those having a meal on the job. For men, it increases the proportion of those who eat in a restaurant, but has little effect on the other two locations. For those who have lunch at home or in a restaurant, working split shifts increases the duration of time spent having lunch.

The other three activities are negatively associated with working split shifts. Female split-shifters spend $12 \mathrm{~min}$ less than comparable straight-shifters on housework on working days. Among males, the figure is 11 min less. As shown in Table B.10, the main contributor to these reductions is time spent shopping for consumer goods and services. Shopping less intensively on working days could be made up for by shopping more intensively on days off. To investigate this possibility, I estimated regressions for shopping time in the full sample of diaries, including among the regressors a binary variable equal to one if the diary pertained to a day off, and an interaction term between this dummy and the dummy for working split shifts. The main results are in Table B.11. By adding the estimate in the interaction term to the estimate on working split shifts, we can see that split-shifters do not shop more

$1128.7 \%$ of straight-shifters sleep $<7 \mathrm{~h}(21.4 \%$ of split-shifters $)$, a lower minimum for the amount of sleep needed to avoid accumulation of fatigue or behavioral impairment (Akerstedt et al. 2009). 


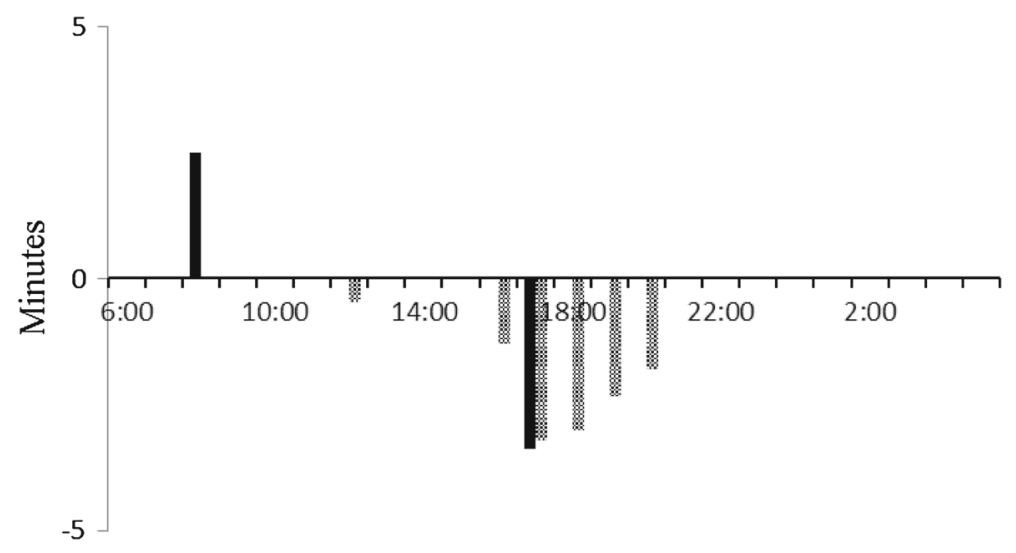

- Women Men

Fig. 4 Effects of working split shifts on parental child care on working days, by time of day and sex. The effects represented are those achieving statistical significance at the $5 \%$ level

intensively than straight-shifters on days off. This result and those in Aguiar and Hurst (2007) suggest that split-shifters might be paying more for the same basket of goods.

Mothers working split shifts devote 3 min less time to child care on a working day than comparable mothers on a straight schedule. The effect, however, is not precise, and does not attain statistical significance. For fathers, working split shifts reduces child care time by approximately $10 \mathrm{~min}$, and this effect is precise. ${ }^{12}$ Among Canadian workers, each additional hour worked before $6 \mathrm{pm}$ substitutes for $5 \mathrm{~min}$ of (direct) maternal child care and 7 min of paternal child care (Rapoport and Le Bourdais 2008, Table 3). Figure 4 shows that, although Spanish mothers working split shifts spend near 4 min less with their children between 5 and $6 \mathrm{pm}$, this is partly offset between 8 and 9 am. Spanish fathers working split shifts also spend less time with their children in the evening, but this reduction extends over more hours and is not offset in the morning. However, the results in Table B.12 indicate that those fathers devote 7 more minutes to child care on days off than comparable fathers on a straight schedule.

Working split shifts reduces leisure time on working days by approximately $7 \mathrm{~min}$ for both women and men. The effect is statistically significant at around the $10 \%$. The main contributor to the reduction for men is in the domain of sports and outdoor activities, which shrinks 10 min (see Table B.13). Males working split shifts do not make up for time lost on days off (see Table B.14), but the evidence suggests that female split-shifters do exercise some 6 min longer on days off than comparable women on a straight schedule.

12 These estimates are robust to the inclusion of a dummy for receiving help with child care by nonhousehold relatives or friends. 
The time-use effects associated with working split shifts do not differ much by gender. To check this hypothesis formally, I re-estimated each time-use regression in the combined sample of men and women, allowing the intercept and all slope coefficients to depend on gender. I then tested whether the interaction term between working split shifts and the dummy for gender was statistically significant. In all five instances, the claim of equality of effects was well within confidence bounds. But if that is the case, why would working split shifts be a significant predictor of ROM2 for women only? One possible explanation is that the common absolute time variations represent different relative time changes. For example, female straight-shifters spend $158 \mathrm{~min}$ at leisure on a working day, whereas their male counterparts spend 199 min, meaning that the common reduction in leisure time associated with a split schedule is relatively more important for women. However, the effect of working split shifts on ROM2 underwent little change when a quadratic function in leisure was included among the regressors.

\subsection{Productivity}

Table 5 presents selected OLS estimates of wage equations by gender and type of wage measure (the complete set of wage effects is given in Table B.15 in the Online Appendix). Odd columns contain the results for WM1 (the hourly wage measure including overtime work), whereas those for WM2 appear in even columns. For both sexes and both wage definitions, wage rates increase with the worker's educational attainment, so that the returns to education are highest for workers having a university degree. In common with the findings of Amuedo-Dorantes and de la Rica (2009), wages are, on average, substantially lower in the private sector, particularly for women.

According to WM1, the productivity of workers on a split schedule is substantially lower than that of comparable straight-shifters: $5.3 \%$ for women and $7.4 \%$ for men. However, removing overtime work (WM2) diminishes significantly those gaps to 2.6 and $3.3 \%$ respectively. All these estimates are precise and achieve statistical significance. Since the extent of overtime work is larger among splitshifters, these results strongly suggest that a sizeable part of the lower return associated with a split schedule as measured by WM1 is due to split-shifters supplying more extra hours for free than straight-shifters, and that this propensity is higher among males. (At stake is the extent to which these extra hours are used productively in the firm or just serve to signal the worker's value.) The results are also consistent with previous findings for OECD countries indicating that the use of overtime hours actually lowers average worker productivity (see Golden 2012, for a survey). The lower productivity of split-shifters as measured by WM2 could be due not only to unobserved characteristics of the workers, but also to how firms are organized (Diaz and Sanchez 2008; Holl 2013) or to the nature of work breaks (Trougakos and Hideg 2009). Firm-level data combined with better measures of worker productivity are likely to prove useful in investigating this issue. 
Table 5 Hourly earnings

\begin{tabular}{|c|c|c|c|c|c|c|c|c|}
\hline \multirow[b]{3}{*}{ Independent variables } & \multicolumn{4}{|l|}{ Women } & \multicolumn{4}{|l|}{ Men } \\
\hline & \multicolumn{2}{|l|}{ (1) Ln WM1 } & \multicolumn{2}{|l|}{ (2) Ln WM2 } & \multicolumn{2}{|l|}{ (3) Ln WM1 } & \multicolumn{2}{|l|}{ (4) Ln WM2 } \\
\hline & Coeff. & SE & Coeff. & SE & Coeff. & SE & Coeff. & SE \\
\hline Split shifts & $-0.053 * * *$ & 0.011 & $-0.026^{* *}$ & 0.011 & $-0.074 * * *$ & 0.010 & $-0.033 * * *$ & 0.009 \\
\hline High school graduate & $0.078 * * *$ & 0.013 & $0.067 * * *$ & 0.012 & $0.097 * * *$ & 0.011 & $0.092 * * *$ & 0.010 \\
\hline University degree & $0.167 * * *$ & 0.019 & $0.155^{* * *}$ & 0.019 & $0.232 * * *$ & 0.020 & $0.220 * * *$ & 0.019 \\
\hline Private sector & $-0.153 * * *$ & 0.019 & $-0.151 * * *$ & 0.019 & $-0.114 * * *$ & 0.018 & $-0.097 * * *$ & 0.018 \\
\hline$R$-squared & 0.522 & & 0.518 & & 0.462 & & 0.465 & \\
\hline Observations & 4041 & & 3934 & & 6476 & & 6359 & \\
\hline
\end{tabular}

Selected OLS estimates. The table shows results for the complete sample of full-time employees. In all estimations, the set of controls includes an intercept plus dummies for age, presence of a spouse/partner, presence of children aged $0-5$ and 6-17, presence of other adults beyond the spouse/partner, disability, education, sector of employment, industry, occupation, flexible work schedule, help to adult family members, and region of residence. The complete set of estimates is shown in Table B.15 in the Online Appendix. Standard errors are clustered at the household level

Source: Spanish time use survey, 2002-2003, INE

** Significant at the $5 \%$ level, *** significant at the 1 percent level

\section{Conclusion}

The type of daytime work schedule has a bearing on the psychological well-being, daily time allocation, and labor productivity of Spanish full-time employees. Other things being equal, on regular working days having a split work schedule is associated with more time spent on the job, sleeping, and eating and drinking, and less time spent doing housework, caring for children (especially by fathers), and on leisure activities. The difference in the labor supply stems mainly from split-shifters providing significantly more overtime than straight-shifters. Straight-shifters sleep less on regular working days because they wake up earlier, do not generally go to bed earlier, and the duration of any nap they take does not compensate for sleep lost in the morning. This finding is in stark contrast to the prediction that straight shifts make for a longer night's rest on working days (ARHOE 2013, pp. 88-89). The lower quantity of domestic work that split-shifters do derives mainly from a reduction in time spent shopping for consumer goods and services. This reduction is not compensated for by shopping more intensively on days off, which suggests that split-shifters may be paying more for the same basket of goods. The lower quantity of child care time provided by fathers working split shifts is partly (28\%) made up on days off. Even so, they devote some 36 min less per week to child care than a comparable father on a straight schedule. The effect of working split shifts on maternal child care time is negative though small, so that it does not seem a major impediment for coordinating work and child caring responsibilities. The lower quantity of leisure is partly made up on days off in the case of women, but not in the case of men.

Although the effects of working split shifts on time allocation are generally similar across the sexes, this is not so in the case of feeling role overloaded. Among male 
full-time employees the type of schedule is unrelated to the role overload condition, but working split shifts increases the feeling among their female counterparts of being at least sometimes overwhelmed by tasks and having too little time to complete them. However, when the definition of role overload is narrowed to the condition of feeling very often overwhelmed by tasks, the type of schedule appears to be irrelevant for women as well. Overall, therefore, working split shifts exerts a lower impact on the likelihood of role overload than other types of shift work (Williams 2008).

Worker productivity appears to be some $6 \%$ lower among workers on a split schedule. However, removing overtime work serves to reduce the productivity gap with respect to straight-shifters to approximately $3 \%$. Since split-shifters provide significantly more overtime, this result strongly suggests that the use of overtime hours lowers worker productivity, whereby working long hours could be impairing company growth and survival probabilities.

Acknowledgments I thank editor Nezih Guner for advice and encouragement, and two anonymous referees for extremely useful comments.

Open Access This article is distributed under the terms of the Creative Commons Attribution 4.0 International License (http://creativecommons.org/licenses/by/4.0/), which permits unrestricted use, distribution, and reproduction in any medium, provided you give appropriate credit to the original author(s) and the source, provide a link to the Creative Commons license, and indicate if changes were made.

\section{Appendix}

See appendix Tables 6, 7 and 8 .

Table 6 Comparison of the economically active population survey with the spanish time use survey

\begin{tabular}{llllllll}
\hline Variable (\%) & \multicolumn{2}{l}{ EAPS } & & \multicolumn{2}{l}{ STUS } \\
\cline { 2 - 3 } & Both & Women & Men & & Both & Women & Men \\
\hline Employment rate & 49.1 & 36.9 & 61.9 & & 50.4 & 38.0 & 63.5 \\
Workers with children [0-4] & 13.0 & 12.0 & 13.6 & & 14.8 & 13.9 & 15.5 \\
Workers with children [0-15] & 32.1 & 31.2 & 32.7 & & 34.4 & 33.5 & 35.0
\end{tabular}

Figures are population estimates for the period October 2002-September 2003. Author's calculations

Table 7 Sample descriptive statistics

\begin{tabular}{|c|c|c|c|c|c|c|c|c|c|c|}
\hline \multirow[t]{2}{*}{ Variable $(\%)$} & \multicolumn{5}{|c|}{ Women } & \multicolumn{5}{|l|}{ Men } \\
\hline & Mean & $\mathrm{SD}$ & Min & $\operatorname{Max}$ & $N$ & Mean & SD & Min & Max & $N$ \\
\hline Role overload Measure 1 & 13.7 & & & & 4041 & 5.7 & & & & 6476 \\
\hline Role overload Measure 2 & 39.4 & & & & 4041 & 22.5 & & & & 6476 \\
\hline \multicolumn{11}{|l|}{ Variable (min) } \\
\hline Sleeping & 454 & 78 & 50 & 840 & 2451 & 455 & 75 & 50 & 870 & 3958 \\
\hline Eating and drinking ${ }^{\mathrm{a}}$ & 85 & 37 & 0 & 280 & 2451 & 94 & 36 & 10 & 330 & 3958 \\
\hline
\end{tabular}


Table 7 continued

\begin{tabular}{|c|c|c|c|c|c|c|c|c|c|c|}
\hline \multirow[t]{2}{*}{ Variable $(\%)$} & \multicolumn{5}{|c|}{ Women } & \multicolumn{5}{|l|}{ Men } \\
\hline & Mean & SD & Min & $\operatorname{Max}$ & $N$ & Mean & SD & Min & $\operatorname{Max}$ & $N$ \\
\hline Housework (excl. child care) $)^{b}$ & 128 & 96 & 0 & 570 & 2451 & 44 & 63 & 0 & 700 & 3958 \\
\hline Child care ${ }^{\mathrm{c}}$ & 53 & 67 & 0 & 470 & 841 & 30 & 53 & 0 & 360 & 1602 \\
\hline Leisure $^{\mathrm{d}}$ & 150 & 99 & 0 & 720 & 2451 & 183 & 103 & 0 & 680 & 3958 \\
\hline Market work ${ }^{\mathrm{e}}$ & 440 & 84 & 70 & 710 & 2451 & 489 & 92 & 30 & 710 & 3958 \\
\hline \multicolumn{11}{|l|}{ Variable (euros of 2002/2003) } \\
\hline Average hourly wage Measure 1 & 6.0 & 3.2 & 1.5 & 32.6 & 4041 & 6.6 & 3.7 & 1.5 & 30.1 & 6476 \\
\hline Average hourly wage Measure 2 & 6.1 & 3.1 & 1.7 & 27.9 & 3934 & 6.9 & 3.6 & 1.7 & 27.9 & 6359 \\
\hline
\end{tabular}

Dependent variables. The upper and lower panels refer to the complete sample of full-time employees, and the middle panel to the subsample whose diary day was a regular working day

Source: Spanish time use survey, 2002-2003, INE

${ }^{a}$ Includes lunch break at work

$\mathrm{b}$ Time spent on food management, household upkeep, making and care for textiles, gardening and pet care, construction and repairs, shopping for consumer goods and services, household management, and help to adult family members

${ }^{\mathrm{c}}$ Parents only

$\mathrm{d}$ Time spent on social life and entertainment, sports and outdoor activities, hobbies and games, and mass media

e Excludes coffee and other breaks and on-the-job training

Table 8 Sample descriptive statistics

\begin{tabular}{|c|c|c|c|c|c|c|c|c|}
\hline \multirow[t]{2}{*}{ Variable } & \multicolumn{4}{|c|}{ Women $(N=4041)$} & \multicolumn{4}{|c|}{$\operatorname{Men}(N=6476)$} \\
\hline & Mean & SD & Min & $\operatorname{Max}$ & Mean & SD & Min & $\operatorname{Max}$ \\
\hline Monthly non-labor income (1000) & 1.3 & 1.0 & 0.0 & 5.5 & 1.0 & 0.8 & 0.0 & 5.3 \\
\hline Commuting (minutes, one-way) ${ }^{\mathrm{a}}$ & 25 & 15 & 0 & 90 & 26 & 16 & 0 & 90 \\
\hline No. of commuting episodes ${ }^{a}$ & 2.5 & 1.0 & 0 & 4 & 2.6 & 1.0 & 0 & 4 \\
\hline \multicolumn{9}{|l|}{ Variable $(\%)$} \\
\hline Split shifts & 43.8 & & & & 55.2 & & & \\
\hline Private sector & 69.1 & & & & 80.0 & & & \\
\hline Flexible work schedule & 20.4 & & & & 20.2 & & & \\
\hline Age $\leq 30$ & 30.3 & & & & 24.1 & & & \\
\hline $31-35$ & 13.6 & & & & 13.4 & & & \\
\hline $36-40$ & 15.6 & & & & 14.8 & & & \\
\hline $41-45$ & 15.3 & & & & 14.5 & & & \\
\hline $46-50$ & 11.6 & & & & 12.9 & & & \\
\hline$\geq 51$ & 13.6 & & & & 20.3 & & & \\
\hline Spouse/partner present & 58.5 & & & & 69.7 & & & \\
\hline Presence of children [0-5] & 14.5 & & & & 17.9 & & & \\
\hline Presence of children [6-17] & 27.9 & & & & 30.7 & & & \\
\hline
\end{tabular}


Table 8 continued

\begin{tabular}{|c|c|c|}
\hline \multicolumn{3}{|l|}{ Variable (\%) } \\
\hline Household with 1 adult & 7.0 & 4.1 \\
\hline 2 adults & 44.7 & 44.5 \\
\hline 3 adults & 21.8 & 23.9 \\
\hline $4+$ adults & 26.5 & 27.5 \\
\hline Less than high school graduate & 34.7 & 51.5 \\
\hline High school graduate ${ }^{b}$ & 34.8 & 30.5 \\
\hline University degree & 30.5 & 18.0 \\
\hline Disabled & 9.7 & 11.1 \\
\hline Manager & 1.2 & 2.9 \\
\hline Technician/professional & 17.8 & 10.8 \\
\hline Supporting technician/prof. & 19.0 & 13.2 \\
\hline Clerical worker & 14.6 & 7.0 \\
\hline Service worker ${ }^{\mathrm{c}}$ & 11.5 & 5.0 \\
\hline Sales worker & 10.2 & 3.6 \\
\hline Craftsman or related worker & 6.5 & 32.0 \\
\hline Operator & 4.4 & 12.7 \\
\hline Unskilled worker & 14.7 & 12.8 \\
\hline Agriculture $^{\mathrm{d}}$ & 1.9 & 4.5 \\
\hline Manufacturing & 15.2 & 26.3 \\
\hline Construction & 1.9 & 20.4 \\
\hline Trade & 17.3 & 12.7 \\
\hline Hotel industry & 5.7 & 1.9 \\
\hline Transport & 3.6 & 5.7 \\
\hline Financial intermediation & 3.1 & 3.8 \\
\hline Real state & 9.7 & 5.4 \\
\hline Public administration & 11.6 & 9.6 \\
\hline Educational services & 10.3 & 4.0 \\
\hline Health services & 12.6 & 2.9 \\
\hline Other services & 7.2 & 2.9 \\
\hline Usual weekly hours worked $<40^{\mathrm{e}}$ & 46.1 & 26.7 \\
\hline$=40$ & 23.2 & 26.0 \\
\hline$>40$ & 30.7 & 47.3 \\
\hline Adult care & 3.6 & 2.0 \\
\hline Net monthly household income $<500$ & 0.8 & 0.7 \\
\hline $500-999.99$ & 7.8 & 10.8 \\
\hline $1000-1499.99$ & 18.5 & 25.2 \\
\hline 1500-1999.99 & 21.5 & 22.4 \\
\hline 2000-2499.99 & 19.9 & 16.8 \\
\hline 2500-2999.99 & 12.3 & 10.1 \\
\hline
\end{tabular}


Table 8 continued

\begin{tabular}{|c|c|c|}
\hline \multicolumn{3}{|l|}{ Variable (\%) } \\
\hline $3000-4999.99$ & 16.3 & 12.0 \\
\hline$\geq 5000$ & 2.9 & 1.9 \\
\hline Andalucía & 15.5 & 19.2 \\
\hline Aragón & 2.7 & 2.5 \\
\hline Asturias & 3.0 & 2.7 \\
\hline Baleares & 2.9 & 2.1 \\
\hline Canarias & 4.6 & 4.2 \\
\hline Cantabria & 3.1 & 3.2 \\
\hline Castilla y León & 4.3 & 4.8 \\
\hline Castilla-La Mancha & 3.4 & 3.7 \\
\hline Cataluña & 19.2 & 17.2 \\
\hline Comunidad Valenciana & 6.3 & 6.7 \\
\hline Extremadura & 1.9 & 1.9 \\
\hline Galicia & 7.8 & 7.8 \\
\hline Comunidad de Madrid & 11.1 & 8.9 \\
\hline Región de Murcia & 2.9 & 3.1 \\
\hline Navarra & 4.5 & 5.0 \\
\hline País Vasco & 2.8 & 2.6 \\
\hline La Rioja & 2.4 & 2.4 \\
\hline Ceuta y Melilla & 1.6 & 1.9 \\
\hline Winter & 27.3 & 26.6 \\
\hline Spring & 26.6 & 26.8 \\
\hline Summer & 23.3 & 23.9 \\
\hline Autumn & 22.8 & 22.6 \\
\hline Monday & 13.3 & 12.6 \\
\hline Tuesday & 13.0 & 12.9 \\
\hline Wednesday & 12.5 & 12.1 \\
\hline Thursday & 12.7 & 12.6 \\
\hline Friday & 16.3 & 16.7 \\
\hline Saturday & 16.1 & 16.1 \\
\hline Sunday & 16.1 & 17.0 \\
\hline
\end{tabular}

Explanatory variables. The table refers to the complete sample of full-time employees. Money variables are in euros of 2002/2003

Source: Spanish time use survey, 2002-2003, INE

a Working days

${ }^{\mathrm{b}}$ Includes vocational training

${ }^{\mathrm{c}}$ Includes the military

${ }^{d}$ Includes extractive industries

e Computed from HM1 


\section{References}

Aguiar M, Hurst E (2007) Life-cycle prices and production. Am Econ Rev 97:1533-1559

Akerstedt T, Nilsson PM, Kecklund G (2009) Sleep and recovery. In: Sonnentag S, Perrewé PR, Ganster DC (eds) Current perspectives on job-stress recovery: research in occupational stress and well being, vol 7. Emerald Group Publishing Limited, Bingley, pp 205-247

Amuedo-Dorantes C, de la Rica S (2009) The timing of work and work-family conflicts in Spain: who has a split work schedule and why? IZA discussion paper no. 4542

Anger S (2008) Overtime work as a signaling device. Scott J Polit Econ 55:167-189

Arellano M, Meghir C (1992) Female labour supply and on-the-job search: an empirical model estimated using complementary data sets. Rev Econ Stud 59:537-557

ARHOE (2013) Horarios, flexibilidad y productividad. VII Congreso Nacional para Racionalizar los Horarios Españoles. Asociación para la Racionalización de los Horarios Españoles

Bell DNF, Hart RA (1999) Unpaid work. Economica 66:271-290

Belsley D, Kuh E, Welsch R (1980) Regression diagnostics: identifying influential data and sources of collinearity. Wiley, New York

Bound J, Brown C, Mathiowetz N (2001) Measurement error in survey data. In: Heckman JJ, Leamer E (eds) Handbook of econometrics, vol 5. Elsevier, Amsterdam, pp 3705-3843

Bureau of Labor Statistics (2005) Workers on flexible and shift schedules in May 2004. United States Department of Labor newsletter, USA

Del Boca D, Flinn C, Wiswall M (2014) Household choices and child development. Rev Econ Stud 81:137185

Diaz MA, Sanchez R (2008) Firm size and productivity in Spain: a stochastic frontier analysis. Small Bus Econ 30:315-323

Eurostat (2004) Guidelines on harmonized European time use surveys. Office for Official Publications of the European Communities, Luxembourg

Fernandez C, Sevilla-Sanz A (2006) Social norms and household time allocation. In: Department of economics discussion paper no. 291. University of Oxford, Oxford

Fisher K, Gershuny J, Altintas E, Gauthier AH (2012) Multinational time use study. In: User's guide and documentation. Version 5-updated. University of Oxford, Oxford

Gimenez-Nadal JI, Molina JA (2013) Parents' education as a determinant of educational childcare time. J Popul Econ 26:719-749

Golden L (2012) The effects of working time on productivity and firm performance: a research synthesis paper. International Labour Office, Conditions of Work and Employment Branch, Geneva

Goux D, Maurin E, Petrongolo B (2014) Worktime regulations and spousal labor supply. Am Econ Rev 104:252-276

Greene WH (1981) On the asymptotic bias of the Ordinary Least Squares estimator of the Tobit model. Econometrica 49:505-513

Greenwood J, Guner N, Kocharkov G, Santos C (2014) Marry your like: assortative mating and income inequality. Am Econ Rev 104:348-353

Guner N, Kaya E, Sánchez-Marcos V (2014) Gender gaps in Spain: policies and outcomes over the last three decades. SERIEs 5:61-103

Hamermesh DS (2002) Timing, togetherness and time windfalls. J Popul Econ 15:601-623

Hamermesh DS, Knowles Myers C, Pocock ML (2008) Cues for timing and coordination: latitude, Letterman, and longitude. J Labor Econ 26:223-246

Holl A (2013) Firm location and productivity in Spain. Investig Reg 25:27-42

INSHT (2003) V Encuesta Nacional de Condiciones de Trabajo. Instituto Nacional de Seguridad e Higiene en el Trabajo. Ministerio de Trabajo y Asuntos Sociales

INSHT (2011) VII Encuesta Nacional de Condiciones de Trabajo. Instituto Nacional de Seguridad e Higiene en el Trabajo. Ministerio de Empleo y Seguridad Social

Juster FT (1985) The validity and quality of time use estimates obtained from recall diaries, institute for social research. In: Juster FT, Stafford FP (eds) Time, goods, and well-being. University of Michigan, Michigan, pp 63-92

Koslowsky M, Kluger AN, Reich M (1995) Commuting stress. In: Causes, effects, and methods of coping. Plenum Press, New York

Kostiuk PF (1990) Compensating differentials for shift work. J Polit Econ 98:1054-1075 
Ligon E (1994) The development and use of a consistent income measure for the General Social Survey. In: GSS methodological report no. 64. NORC, University of Chicago, Chicago

Manning A (2010) Imperfect competition in the labor market. In: Card D, Ashenfelter O (eds) Handbook of labor economics, vol 4b. Elsevier, New York, pp 973-1042

Presser HB (1988) Shift work and child care among young dual-earner American parents. J Marriage Fam 50:133-148

Presser HB (1994) Employment schedules among dual-earner spouses and the division of household labor by gender. Am Sociol Rev 59:348-364

Rapoport B, Le Bourdais C (2008) Parental time and working schedules. J Popul Econ 21:903-932

Robinson JP (1985) The validity and reliability of diaries versus alternative time use measures, institute for social research. In: Juster FT, Stafford FP (eds) Time, goods, and well-being. University of Michigan, Michigan, pp 33-62

Stapleton DC, Young DJ (1984) Censored normal regression with measurement error on the dependent variable. Econometrica 52:737-760

Stewart J (2013) Tobit or not Tobit? J Econ Soc Meas 38:263-290

Stoker TM (1986) Consistent estimation of scaled coefficients. Econometrica 54:1461-1481

Trougakos JP, Hideg I (2009) Momentary work recovery: the role of within-day work breaks. In: Sonnentag S, Perrewé PR, Ganster DC (eds) Current perspectives on job-stress recovery: research in occupational stress and well being, vol 7. Emerald Group Publishing Limited, Bingley, pp 37-84

Williams C (2008) Work-life balance of shift workers. Perspect Labour Income 20:15-26

Wooldridge JM (2010) Econometric Analysis of Cross Section and Panel Data, 2nd edn. The MIT Press, Cambridge, MA 